\title{
The Principle of Sustainable Development in Catholic Social Teaching
}

\author{
Miroslav Kněz, Roman Míčka
}

\begin{abstract}
"If we do not learn to energetically limit our requirements and demands, to subordinate our interests to moral imperatives, we as human species will perish. If one does not orient oneself to higher values than one's own egoistic self, depravity and deterioration inevitably prevails."

"There was a thing, as I've said before, called Christianity.... The ethics and philosophy of under-consumption..." Aldous Huxley, Brave New World, 1932

"The way humanity treats the environment influences the way it treats itself, and vice versa. This invites contemporary society to a serious review of its life-style, which, in many parts of the world, is prone to hedonism and consumerism, regardless of their harmful consequences. What is needed is an effective shift in mentality which can lead to the adoption of new life-styles..."

Caritas in veritate, par. 51

Sustainable human activity in interaction with the natural environment and processes is a grave issue and question posed in the realm of ecology, economy, and politics. In this paper we attempt - after briefly sketching the development and contents of the concept, as well as debates over it - to look for possible connections and harmony between the concept of sustainable development (further SD) and the so-called Catholic social teaching (further CST). CST (or Social Doctrine of the Church, Ecclesiae doctrina socialis), usually expressed in the official documents of the Catholic Church, addresses current political, economic, and social issues. It is neither a direct political program nor a set of instructions for implementing politics, "but rather the accurate formulation of the results of a careful reflection on the complex realities of human existence, in society and in the international order, in the light of faith and of the Church's tradition".' In its core CST contains an expression of fundamental Christian values and truths concerning humanity, which it attempts to apply to the social order, and thereby to "...dialogue with the various disciplines concerned with man. It assimilates what these disciplines have to contribute, and helps them to open themselves to a broader horizon, aimed at serving the individual person who is acknowledged and loved in the fullness of his or her vocation". ${ }^{2}$ As already mentioned, it does not claim exclusivity or infallibility in evaluating political and economic realities, it even acknowledges a certain "experiential dimension"3 and legitimacy of a plurality of views and strategies in the realization of the values promoted by CST. ${ }^{4}$ At first the ecological dimension was not easily apparent in the CST, but at present it is becoming one of its essential aspects. 


\section{Development of the concept of SD}

Sustainable development was first mentioned already in the $19^{\text {th }}$ century, ${ }^{5}$ but the contemporary content of the concept began to develop in the 1970s, when in 1972 the Roman Club ${ }^{6}$ initiated the publication of a scientific study called Limits of Growth. The study points out the unsustainability of economic growth in the future, when it will have crossed its sustainable limits. The solution to this unfavourable prognosis it offers is limiting economic growth or discontinuing it altogether. The development of the predictions sketched was confirmed in 1992 by a further study Beyond the Limits. ${ }^{7}$ At that time sustainability became an issue at the UN conferences on the environment. The first of these held in Stockholm in 1972 proclaimed the right to the environment to be one of the fundamental human rights. In 1980 three world organizations (the International Union for Conservation of Nature - IUCN, the United Nations Environment Programme - UNEP, and the World Wildlife Fund - WWF) together elaborated the document World Conservation Strategy (WCS), the first official document employing the concept SD. In 1983 the UN founded the World Commission on Environment and Development, which was to propose strategies ensuring the sustainability of development. In 1987 it published a proposal in the form of a document entitled Our Common Future, also known as the Brundtland Report, ${ }^{8}$ in which the first definition of development respecting the principle of sustainability appeared: "...sustainable development, which implies meeting the needs of the present without compromising the ability of future generations to meet their own needs..."

Since then sustainable development has become a long-term integral conception, which underlines the interconnectedness of economic, ecological, and social factors. A considerable shift from general to more specific strategy was offered by the second conference, held in 1992 in Rio de Janeiro, focused on the environment and development. This summit adopted a Declaration (27 principles of SD) and a document called Agenda 21 (on the shift to SD) aimed at achieving harmony between economic and social development and effective protection of the environment. In the same year the United Nations Commission on Sustainable Development (CSD) was established, which was to reflect the observation of Agenda 21. There followed the so-called "Summit of the Millennium" in 2000, where aims with respect to sustainability up to 2015 were formulated. The third UN conference on SD was held in Johannesburg in 2002. Although as compared to the previous undertakings it was more specific in content, ${ }^{10}$ its outputs (the Johannesburg Declaration and Implementation Plan) remained at the general level of moral appeal to individual states. Specific measures concerning sustainable management of natural resources were not offered by its conclusions. ${ }^{11}$

We could discuss the implementation of the principles of SD into the legislation of the EU or specific states. ${ }^{12}$ This only applies to a local continent or state and does not solve the problem

5 E.g. by Thomas R. Malthus with his understanding of sustainability as the principle maintaining balance between minimal wages and production. The main criterion of sustainability is the number of inhabitants, which is the limit of unsustainable growth.

6 A supranational research institute founded in 1968 with the aim of evaluating the effects of governmental and non- governmental politics on public life.

7 Karel TOMŠíK, Evropská integrace a environmentální ekonomika, Praha: Česká zemědělská univerzita, 2009, p. 96.

8 Gro H. BRUNDTLANDOVÁ and others, Naše společná budoucnost, Praha: Academia, 1991, p. 43.

9 (C) UN Resolution A/RES/42/187. Report of the WCED /1987/ (on-line), at: http://www.un-documents.net/a42r187.htm, retrieved August 21, 2014.

10 The topics are: globalization, poverty and the millennial goals of development, model of consumption and production, protection of biodiversity and natural resources, harmonization of development and the environment.

11 Cf. Karel TOMŠÍK, Evropská integrace a environmentální ekonomika, pp. 100-101.

12 E.g. in the Czech Republic according to $\S 6$ of law no. 17/1992 Sb., on the environment: "Sustainable development of society is development which preserves the possibility of meeting the basic needs of present and future generations and at the same time does not decrease natural diversity and maintains the natural functions of ecosystems." Cf. Law no. 17/1992 Sb., on the environment (on-line), at: http://goo. gl/2d1AzA, retrieved August 21, 2014. 
in global context, because in only considers the interests of the given area, whose sustainability need not always follow the development in other countries. A further global summit on the development and implementation of SD is as yet expected.

With respect to what is discussed above and below let us add that the debate led in the field of development, ecology, and ecoethics is colourful and complex. Although there exists basic agreement concerning the necessity of protecting the environment and conserving it for the future generations of humanity, there still prevail fundamental disputes over the political forms of solution, necessary priorities, measure of immediacy of the individual problems, as well as the possibilities of decreasing civilizational demands and human consumption. On the one hand, the several-decades-long ecological debate has shown that sceptical prognoses concerning the possibilities of development, limits, and resource exhaustion have frequently not proved adequate or were disproportionately pessimistic; on the other hand, despite the great uncertainty of future prognoses there exists wide consensus concerning the need for a practical application of the principle of responsibility. In the words of Hans Jonas: "the prophecy of doom is to be given greater heed than the prophecy of bliss". ${ }^{13}$ However, the principle of preliminary caution should not become a means of legitimating the blocking of reasonable integral growth and raising disproportionate and apocalyptic fears. Despite catastrophic predictions of resource exhaustion and overpopulation it turns out that fears have often been disproportionate. Yet it is evident that civilizational prosperity developed in the context of the Western civilization cannot be applied in global context and that in close perspective it is necessary to choose a more moderate and abstemious lifestyle, for which the mentality and moral maturity of the more developed as well as developing societies is as yet unprepared.

\section{Development and "sustainable development" in CST}

Of course, the concept of development is frequently employed is CST documents, though in the older ones the primary meaning is economic, political, technical, and scientific development - the ecological dimension of development is not distinctively stressed. The ecological dimension of human activity has been more fully present in CST since the pontificate of John Paul II. The relationship of the economic and ecological dimension of development is first discussed in its complexity in the encyclical Caritas in veritate (2009) by Benedict XVI.

In the original Latin text of the documents various terms translated as progress or development are used (progressus, profectum, incrementum). As an example representing many instances we can cite one of the classical definitions of the so-called "human person principle", considered to be the highest principle of CST: ${ }^{14}$

"Man's social nature makes it evident that the progress of the human person and the advance of society itself hinge on one another. For the beginning, the subject and the goal of all social institutions is and must be the human person which for its part and by its very nature stands completely in need of social life." 15

The definition shows that development and progress are held to be an essential aspect of the human being and society, to be directed to the human person as the goal of all political and

13 Hans JONAS, Princip odpovědnosti: Pokus o etiku pro technologickou civilizaci, Praha: Oikoymenh, 1997, p. 62.

14 Cf. Mater et magistra, art. 219-220.

15 Gaudium et spes, art. 25. 
economic effort. Both the constitution Gaudium et spes and other CST documents of the time view nature as exclusively (prevalently) subordinated to the goals of human effort, they speak of the trend of consolidating control over nature by means of science and technology. ${ }^{16}$ Despite the already at the time expressed fears of possible overpopulation and lack or exhaustion of resources, CST softens down such concern and expresses optimism:

"Truth to tell, we do not seem to be faced with any immediate or imminent world problem arising from the disproportion between the increase of population and the supply of food. Arguments to this effect are based on such unreliable and controversial data that they can only be of very uncertain validity. Besides, the resources which God in His goodness and wisdom has implanted in Nature are well-nigh inexhaustible, and He has at the same time given man the intelligence to discover ways and means of exploiting these resources for his own advantage and his own livelihood... The progress of science and technology that has already been achieved opens up almost limitless horizons in this field."17

The contents of the encyclicals clearly show that they underline especially dynamic economic development, which would result in the elimination of poverty and undignified conditions of human life in the world, especially in poor and developing countries. This dimension is most stressed by the encyclical Populorum progressio on the development of nations (1967):

"The progressive development of peoples is an object of deep interest and concern to the Church. This is particularly true in the case of those peoples who are trying to escape the ravages of hunger, poverty, endemic disease and ignorance; of those who are seeking a larger share in the benefits of civilization and a more active improvement of their human qualities; of those who are consciously striving for fuller growth."18

The encyclical more explicitly speaks of man's complete development (lat. homo plene excolatur), ${ }^{19}$ or even of the integral development of humanity: "The development We speak of here cannot be restricted to economic growth alone. To be authentic, it must be well rounded (lat. integra); it must foster the development of each man and of the whole man." ${ }^{20}$ Besides the economic dimension, Pope Paul VI means also other dimensions of the human existence, especially religious, cultural, and ethical. Even though the encyclical Populorum progressio stressed the need for development not oriented exclusively on the economic dimension, the ecological aspect is not as yet present. But in contrast to the encyclical mentioned above it does not speak of the "limitless" possibilities of nature, it rather speaks of "depletion of natural resources", though it sees the core of the problem in "the weakening of brotherly ties between individuals and nations." 21

The apostolic letter of Pope Paul VI Octogesima adveniens (1971) is already more critical of constant economic growth and consumption as the ideals of progress; against reducing development to its economic dimension it posits "true progress in the development of moral consciousness". Civilization has invested too much hope "...in ceaselessly renewed and indefinite progress" and values quantity to the detriment of quality. ${ }^{22}$ The letter also explicitly mentions ecological issues and disconsolate trends in the relationship of humanity and nature, it even speaks of "exploitation" and "degradation":

\footnotetext{
16 Cf. ibid., art. 9, 33.

17 Mater et magistra, art. 188-189.

18 Populorum progressio, art. 1.

19 Cf. ibid., art. 5.

20 Ibid., art. 14.

21 Both ibid., art. 66.

22 All Octogesima adveniens, art. 41.
} 


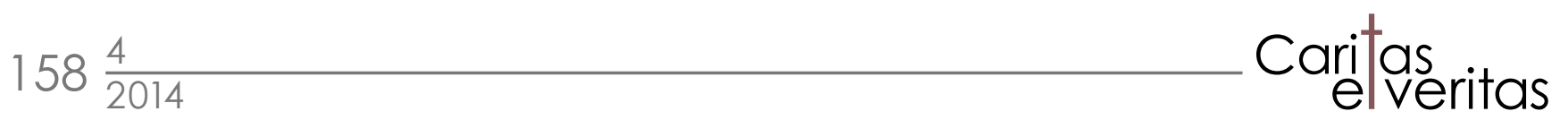

"While the horizon of man is thus being modified according to the images that are chosen for him, another transformation is making itself felt, one which is the dramatic and unexpected consequence of human activity. Man is suddenly becoming aware that by an ill-considered exploitation of nature he risks destroying it and becoming in his turn the victim of this degradation. Not only is the material environment becoming a permanent menace - pollution and refuse, new illness and absolute destructive capacity - but the human framework is no longer under man's control, thus creating an environment for tomorrow which may well be intolerable. This is a wide-ranging social problem which concerns the entire human family." 23

With the era of John Paul II (1978-2005), concurrently with the general sharpening of ecological consciousness, there comes greater emphasis on ecological issues and the ecological dimension of human development. In 1979 the Pope declared St. Francis of Assisi the patron saint of ecology. The Pope underlines ecological issues in all his social encyclicals, both in Laborem exercens (1981), where he points out the theological dimension of the relationship of humans and nature, and in Solicitudo rei socialis (1987), where he further elaborates and enriches the concept of integral development from the encyclical Populorum progressio. In the context of a 20-year distance and the situation of the Cold War he cools down the optimism concerning development, ${ }^{24}$ criticizes the phenomenon of super-development and consumerism, ${ }^{25}$ and views ecological thinking in connection with development as a sign of the times:

"Among today's positive signs we must also mention a greater realization of the limits of available resources, and of the need to respect the integrity and the cycles of nature and to take them into account when planning for development, rather than sacrificing them to certain demagogic ideas about the latter. Today this is called ecological concern." 26

Other of his papal documents have become famous for ecological emphases as well, e.g. Message for the Celebration of the World Day of Peace of 1990, called Peace with God the Creator, Peace with All of Creation, where he calls for formation of "ecological consciousness", denounces specific aspects of damaging nature and calls for including a new human right "to a safe environment" in the Charter of Human Rights. Essential aspects of the topic are gathered in the Pope's last social encyclical Centesimus annus (1991), where he says that earlier stages of human development were primarily engaged with questions of poverty and satisfying basic human needs. But the dynamics of development has brought new issues and new dangers, especially "the phenomenon of consumerism", which one-sidedly addresses the instinctive aspect of human beings and does not distinguish artificial and unnecessary needs from real ones. ${ }^{27}$ The issue of ecology is taken to be closely connected to that of consumerism: "In his desire to have and to enjoy rather than to be and to grow, man consumes the resources of the earth and his own life in an excessive and disordered way." 28 However, the Pope considers moral issues to be even more important than ecological ones, whereby he means first of all the practical and ideological deterioration of the natural family, abortion, euthanasia, homosexuality, and other phenomena of the socalled "culture of death":

"In addition to the irrational destruction of the natural environment, we must also mention the more serious destruction of the human environment, something which is by no means receiving the attention

\footnotetext{
23 Ibid., art. 21.

24 Cf. Solicitudo rei socialis, art. 12.

25 Cf. ibid., art. 28.

26 Ibid., art. 26.

27 Cf. Centesimus annus, art. 36.

28 Ibid., art. 37.
} 
it deserves. Although people are rightly worried - though much less than they should be - about preserving the natural habitats of the various animal species threatened with extinction, because they realize that each of these species makes its particular contribution to the balance of nature in general, too little effort is made to safeguard the moral conditions for an authentic "human ecology". Not only has God given the earth to man, who must use it with respect for the original good purpose for which it was given to him, but man too is God's gift to man." ${ }^{29}$

In John Paul II's less formal speeches and texts than are the deeply reflected and balanced documents for the whole Church the Pope often uses very strong and colourful rhetoric, which leaves no one in doubt as to how seriously he received the ecological issue. An example is an excerpt from his speech at the general audience on January 17, 2001:

"Unfortunately, if we scan the regions of our planet, we immediately see that humanity has disappointed God's expectations. Man, especially in our time, has without hesitation devastated wooded plains and valleys, polluted waters, disfigured the earth's habitat, made the air unbreathable, disturbed the hydrogeological and atmospheric systems, turned luxuriant areas into deserts and undertaken forms of unrestrained industrialization, degrading that "flowerbed" - to use an image from Dante Alighieri (Paradiso, XXII, 151) - which is the earth, our dwelling-place. We must therefore encourage and support the "ecological conversion" which in recent decades has made humanity more sensitive to the catastrophe to which it has been heading." 30

Benedict XVI (2005-2013) continues in the line of John Paul II, he most fundamentally and complexly elaborates the topic in the encyclical Caritas in veritate (2009), dedicated to the $40^{\text {th }}$ anniversary of the encyclical Populorum progressio. There the Pope develops the concept of integral development in all respects and in the context of the current situation as well as of ideological disputes, including the ecological dimension, which is discussed in the most complex way. The key concept of integral development occurs already in the encyclical's subtitle On Integral Human Development in Charity and Truth (lat. De humana integra progressione in caritate veritateque). Benedict XVI praises Paul VI for his incentives to the concept of integral development, which he further contextualizes, enriches, ${ }^{31}$ and especially sets in the context of reflecting on love (lat. caritas), which is "...the principal driving force behind the authentic development of every person and of all humanity", ${ }^{32}$ while love for truth (lat. caritas in veritate) is the principle from which all of CST is derived. ${ }^{33}$ Concerning the reception of the key concept "sustainable development", this can be found directly in article 21, which says that economic development producing real growth and beneficial to all is "genuinely sustainable" (lat. sustinendum). The expression "sustainable development" or "true sustainable development" is used in the $4^{\text {th }}$ case (lat. veram sustinendam progressionem) in article 65 of the encyclical Caritas in veritate; however in the English version this is translated as "sustaining true development". The ecological dimension of development is underlined especially in articles 48-52, where the theological dimension is reviewed and aspects of the issue of energy, use of non-renewable resources, energetic demands, and climate protection are emphasised. At the same time one must not fail to perceive the polemical tone which the Pope employs with respect to some ecological concepts of "non-anthropocentric" character:

\footnotetext{
29 Ibid., art. 38.

30 JOHN PAUL II, General Audience (17 January 2001), art. 3-4.

31 Cf. Caritas in veritate, art. 21.

32 Ibid., art. 1.

33 Ibid., art. 6.
} 


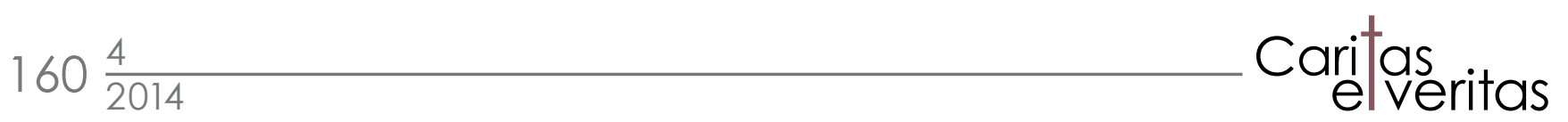

"But it should also be stressed that it is contrary to authentic development to view nature as something more important than the human person. This position leads to attitudes of neo-paganism or a new pantheism." 34

The Pope underlines the primacy of the human person in questions of development and ecology, which must have neither technocratic, nor biocentric or ecocentric character. He thus criticizes radical ecologism and romantic views and ideologies concerning nature:

"Unfortunately the negative ideologies continue to flourish... If on the one hand, some today would be inclined to entrust the entire process of development to technology, on the other hand we are witnessing an upsurge of ideologies that deny in toto the very value of development, viewing it as radically anti-human and merely a source of degradation." 35

In contrast to that he stresses the importance of cultural, institutional, and moral, not merely material nature of the quality and quantity of development. ${ }^{36} \mathrm{He}$ posits responsible freedom against technocratic solutions ${ }^{37}$ and prefers incorporating poor countries into global market processes to non-efficient development aid (criticism of customs tariffs). ${ }^{38}$ At the same time he calls for a revision of lifestyle, especially in developed countries ("The way humanity treats the environment influences the way it treats itself, and vice versa. This invites contemporary society to a serious review of its life-style, which, in many parts of the world, is prone to hedonism and consumerism, regardless of their harmful consequences. What is needed is an effective shift in mentality which can lead to the adoption of new life-styles..." ${ }^{39}$ ), and does not hesitate to stress the inability of rich countries to "distinguish what is human" and to criticize, as John Paul II had done, the structures of the "culture of death":

"Yet we must not underestimate the disturbing scenarios that threaten our future, or the powerful new instruments that the "culture of death" has at its disposal. To the tragic and widespread scourge of abortion we may well have to add in the future - indeed it is already surreptitiously present - the systematic eugenic programming of births. At the other end of the spectrum, a pro-euthanasia mindset is making inroads as an equally damaging assertion of control over life... Underlying these scenarios are cultural viewpoints that deny human dignity." 40

In his Message for the Celebration of the World Day of Peace of 2010, subtitled If You Want to Cultivate Peace, Protect Creation, Pope Benedict further develops and brings up to date some aspects of ecology - he speaks of the need for a "profound, long-term review of our model of development", calls for a "profound cultural renewal" of humanity and rediscovering values constituting a firm foundation for the prevention of crisis in "economic, food-related, environmental or social" sphere. ${ }^{41}$ In the sphere aimed at sustainable development he speaks of intergenerational solidarity ("A greater sense of intergenerational solidarity is urgently needed. Future generations cannot be saddled with the cost of our use of common environmental resources" ${ }^{42}$ ) and in fact receives the frequently stressed issue of so-called externalities ("When making use of natural resources, we should

\footnotetext{
34 Ibid., art. 48.

35 Ibid., art. 14.

36 Cf. ibid., art. 19 and 22.

37 Cf. ibid., art. 17.

38 Cf. ibid., art. 33 and 58.

39 Ibid., art. 51.

40 Ibid., art. 75.

41 All cf. BENEDICT XVI., Message for the Celebration of the World Day of Peace (2010), art. 5.

42 Ibid., art. 8.
} 
be concerned for their protection and consider the cost entailed - environmentally and socially - as an essential part of the overall expenses incurred" 43 ).

Pope Francis (2013-present) has not so far developed these issues beyond the scope of the preceding popes, even though considering the name he has chosen as well as the ecological emphases in his speeches so far further development can be expected. The concept of sustainable development is directly mentioned in his exhortation Evangelii gaudium (2013), where he says that the "conditions for a sustainable and peaceful development have not yet been adequately articulated and realized", ${ }^{44}$ though he does not interpret it in any new way. Since January 2014 the media have announced ${ }^{45}$ that Pope Francis intends to write and publish a new encyclical on the relationship of humans and nature.

\section{Debate concerning the character of ecoethics and the concept of SD within Christian ethics}

Since the publication of Lynn White's paper The Historical Roots of Our Ecologic Crisis (1967), which claimed that the fundamental cause of the ecological crisis is Christian anthropocentrism, there exists a live debate concerning Christian ethical attitudes to the environment, which is still in progress. The development of official Catholic attitudes as presented by CST sketched above shows that the Church has reacted to the substance of the criticism, as well as the overall level of increasing ecological awareness, in a fundamental way. Apart from the tradition of CST there is also a whole broad current of theological and Christian-ethical thinking, which reflects these issues in various aspects and contexts. Since the 1960s variations of theology of creation, theology of matter, theologies of development have been developing in both Catholic and Protestant milieu, many of which are briefly presented by Karel Skalický in his book Po cestách angažované teologie - Teologie křest'anské praxe. ${ }^{46}$ Some of their elements play a certain part in the ecoethical debate and some have rather more radical implications that exceed the intentions of CST outlined above. Some of them are even so radical that they are controversial and are not considered to be part of the "mainstream" debate oscillating between the poles of moderate anthropocentrism and ecocentrism. ${ }^{47}$

Theological thought with ecological accents points out the possible biblical and theological sources of a moderate ecological view of the world. However, both the points of departure and the practical implications differ widely. The debate takes place on a scale ranging from fairly radical Christian-inspired ecoethics, which cooperates even with the more radical ecological movements, to fairly conservative views, which criticize radical ecologism and are rather inspired by the so-called "anti-ecological" currents. An example of the former is the Czech evangelical theologian Erazim Kohák, member of the honorary board of Hnutí Duha, of the presidium of the Society for Sustainable Life on Earth, of the honorary board of the movement Children of the Earth and member of the Czech Social Democratic Party. His well-known and respected book The Green Aureola ${ }^{48}$ presents the fundamental views of ecological issues as well

43 Ibid., art. 7.

44 Evangelii gaudium, art. 59 .

45 Cf. e.g. the article Vztah člověka a př́rody? Papež František píše biskupům list o ekologii /2014/ (on-line), at: http://goo.gl/Y5HyDF, retrieved August 21, 2014.

46 Karel SKALICKÝ, Po cestách angažované teologie. Teologie křestáanské praxe, Praha: Ježek, 2001.

47 Cf. e.g. the rather pantheistic conception of Matthew Fox (Matthew FOX, Příchod kosmického Krista: uzdravení Matky Země a počátek globální renesance, Brno: CDK, 2004), or the work of the non-conformist moral theologian Eugen Drewermann (Eugen DREWERMANN, O nesmrtelnosti zviŕat: naděje pro trpící stvoření, Košice: Knižná dielňa Timotej, 1998).

48 Cf. Erazim KOHÁK, Zelená svatozář kapitoly z ekologické etiky, Praha: Sociologické nakladatelství, 2000. 


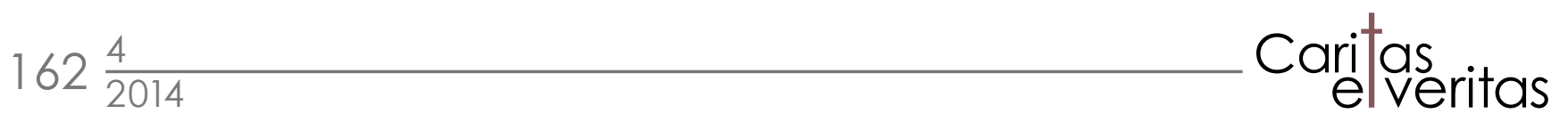

as the author's view, which is critical of some forms of ideologism, activism, and romantic approach to ecology, while at the same time finding some inspiration in all streams - he is reluctant to present too definite, ready-made answers and advocates "ecological literacy" and modest lifestyle. His conception can also be seen as "theocentric". ${ }^{9}$ An example of the latter may be the American neo-conservative theologian Michael Novak, fairly well-known in the Czech context, who advocates so-called "blue environmentalism". Novak is critical of "green environmentalism" for its ecocentrism, for sceptical or even apocalyptic perception of reality, socialist conception of economy, and fear of overpopulation and depletion of resources. ${ }^{50} \mathrm{He}$ proposes eradicating world poverty by means of spreading the institutions of capitalism, and following the example of the American economist Julien Simon harbours great trust in human creativity and invention - "the inexhaustible resource". Even though the debate is broad and structured, and frequently concerns not only fundamental value notions (human beings and their worth, position in the context of nature, etc.), but also the character and forms of possible solutions to ecological problems (the question of priorities, possibility of regulation, etc.), the fundamental point of debate between Christian ecoethics and other value conceptions is the question of the legitimacy of "Christian anthropocentrism". In the context of Christian anthropology human beings are the apex of creation and its custodians, who greatly exceed the natural world in worth and importance. Though Christian ethics has in recent decades come to appreciate the (perhaps earlier neglected) ecological dimension, it still insists on the (more or less) anthropocentric character of creation, where CST belongs among the more anthropocentric varieties, for which it has been subject to appropriate criticism. An example of moderate criticism may be e.g. the paper Environmental Analysis of the Social Encyclicals of John Paul II by Radim Kindl. ${ }^{51}$ Although Kindl appreciates the ecological dimension of CST as an excellent contribution to the debate concerning the ecological crisis, he thinks that John Paul II has a too anthropocentric view of creation and derives "the value of nature from its purposes for humanity as a whole", ${ }^{52}$ whereby he neglects, or only weakly outlines the value of nature in itself, or the "theocentric" dimension of creation. In the concluding evaluation Kindl states that although "the Catholic Church remains in the bonds of anthropocentrism", which "weakens the effort of some theologians at a non-anthropocentric interpretation of the Christian message and limits the possibilities of searching for an adequate relationship of humans and nature in the social teaching of the Church", there is nonetheless some agreement between the Pope's conception of progress and the conception of SD, which creates space for cooperation between environmentalists and Catholics. ${ }^{53}$ Two examples show that Kindl's views are in some aspects radical, when he e.g. construes human work not as cultivating the world and cooperating in creation, but exclusively as devastating activity increasing entropy in nature. He also finds unacceptable the Pope's emphasis on sexual morality and rejection of contraception, which according to him could "hinder true development" in many countries. ${ }^{54}$

However, in the spirit of searching for consensus and common value-related points of departure the debate concerning convergence and agreement between Christian ecoethics and broadly conceived environmentalism is lively. When we examine the reflection of the concept of SD once again, we find that some interpreters of CST consider the possible widening

49 Cf. e.g. one of Kohák's newest papers: Erazim KOHÁK, Bůh přírody, Bůh můj, in: František ŠTĚCH and Roman MíČKA eds., Církev a společnost. Karlovi Skalickému k 80. narozeninám, České Budějovice: TF JU, 2014, pp. 281-288.

50 Cf. Michael NOVAK, The Universal Hunger for Liberty. Why the Clash of Civilizations Is Not Inevitable, New York: Basic Books, 2004, pp. 113-133.

51 Cf. Radim KINDL, Environmentální analýza sociálních encyklik Jana Pavla II., in: Petr FIALA - Jiří HANUŠ - Jan VYBÍRAL eds., Katolická sociální nauka a současná věda, Brno: CDK, 2004, pp. 171-189.

52 Ibid., p. 175.

53 All ibid., p. 187.

54 Ibid., p. 184. 
or synchronization with the set of fundamental, traditionally enumerated principles of CST (principle of the human person, of solidarity, of subsidiarity, of justice, of the common good) by the principle of SD. This idea is most complexly elaborated by Markus Vogt in his book Prinzip Nachhaltigkeit: Ein Entwurf aus theologisch-ethischer Perspektive (2009), ${ }^{55}$ though the idea itself is older and preceded by a certain debate in the German-speaking world - e.g. the paper Nachhaltigkeit: Vom Schlagwort zum Prinzip (2004) by Helge Wulsdorf and Thomas Schärtl ${ }^{56}$ or similarly-minded papers by the already mentioned Markus Vogt, the initial of which is probably Das neue Sozialprinzip "Nachhaltigkeit" als Antwort auf die ökologische Herausforderung (1999)..$^{57}$ The authors conclude that the principle of SD is in fact a broadening of the principle of justice within human society to intergenerational context, i.e., concerning future generations of humans, and further beyond the relationship of humans and society towards the relationship of human beings and nature, or the whole of creation. The American Catholic authors Russell Butkus and Steven Kolmes in their paper Ecology and the Common Good: Sustainability and Catholic Social Teaching (2007) ${ }^{58}$ endorse a similar view, but they rather link the principle of SD to the classical principle of the common good, which they consider to be an umbrella principle of the CST. The common good (lat. bonum commune) is defined as "...the sum of those conditions of social life which allow social groups and their individual members relatively thorough and ready access to their own fulfillment...". ${ }^{59}$ According to the authors the ecological dimension of this principle, which as a pre-condition of social conditions assumes the dependence of the human species on the environment and is deeply connected to the dimension of justice, is becoming ever more apparent. This entire debate preceded the publication of Benedict XVI's encyclical Caritas in veritate (2009), which receives and employs the concept of SD, though it does not propose a definition of it or proclaim SD as a specific principle.

\section{Conclusion}

The ecological crisis and environment destruction are signs of the times, to which CST adequately reacts and which it reflects. In the process of intensification of ecological consciousness CST has gradually received the concept of SD in its basic meaning of intergenerational solidarity and respect to nature. However, it sets it in the broader concept of integral human development and underlines the anthropological dimension of ecological issues in the context of biblical and theological anthropology. Besides ecological and economic-developmental accents it fundamentally stresses the dimension of human dignity and life from natural beginning to natural end. Thus it does not identify with the more radical ecological conceptions, which are ecocentric or biocentric in character and are overly sceptical to the perspective of the dynamics of further development, or conversely to the need to limit consumerism.

In the context of these debates CST itself may appear as a medium position appreciating the emphases and values of both poles of the debate in an effort at a balanced reflection. It does not hold sceptical, radical, or apocalyptic positions and harbours trust in human beings and their ability to develop creatively in harmony with the created order while meeting their basic needs. At the same time it does not side with the radical critics of "ecologism" and does not

\footnotetext{
55 Markus VOGT, Prinzip Nachhaltigkeit: Ein Entwurf aus theologisch-ethischer Perspektive, München: Oekom Verlag, 2009.

56 Helge WULSDORF and Thomas SCHÄRTL, Nachhaltigkeit: Vom Schlagwort zum Prinzip, Ethica 12/2004 (2), pp. 137-162.

57 Markus VOGT, Das neue Sozialprinzip „Nachhaltigkeit“ als Antwort auf die ökologische Herausforderung, in: Handbuch der Wirtschaftsethik, Gütersloh: Gütersloher Verlagshaus, 1999, pp. 237-257.

58 ( ) Russell BUTKUS - Steven KOLMES, Ecology and the Common Good: Sustainability and Catholic Social Teaching, Journal of Catholic Social Thought 4/2, 2007, pp. 403-436 (on-line), at: http://goo.gl/KXzN5d, retrieved August 21, 2014.

59 Gaudium et spes, art. 26.
} 


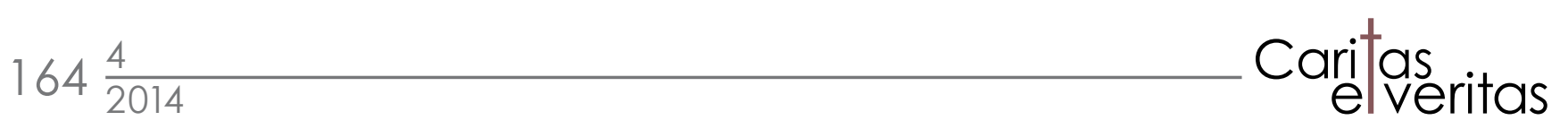

support the idea of unlimited possibilities of progress and consumption. Due to its ethical anthropocentrism it cannot accept ecocentric or biocentric positions, which often want to solve ecological issues to the detriment of adequate economic development, free market economy, or by quantitative elimination of the human population. That is why CST will be in permanent dispute with efforts to solve ecological problems to the detriment of humans, of maintaining their life and dignity. Its emphasis on culture of life will be in permanent opposition to new and powerful instruments of the "culture of death", which often shroud in the agreeable garment of ecological emphases. With its accent on revising lifestyles and moderating consumption it can markedly contribute to cultivating sustainable integral development of humanity and the natural environment. The "anthropocentric" attitudes of CST are probably best defined in the as yet unmentioned Compendium of the Social Doctrine of the Church (2004), which presents a systematic and complex overview of CST and occasionally interprets and comments on classical social encyclicals and other texts:

"A correct understanding of the environment prevents the utilitarian reduction of nature to a mere object to be manipulated and exploited. At the same time, it must not absolutize nature and place it above the dignity of the human person himself. In this latter case, one can go so far as to divinize nature or the earth, as can readily be seen in certain ecological movements that seek to gain an internationally guaranteed institutional status for their beliefs. The Magisterium finds the motivation for its opposition to a concept of the environment based on ecocentrism and on biocentrism in the fact that it is being proposed that the ontological and axiological difference between men and other living beings be eliminated..." 60

Concerning the anthropocentric emphasis, CST is rather more conservative than the views and convictions of some Christian ecological ethicists and theologians, who underline the theocentric character of creation. To partially defend CST we can state that despite the undeniable presence of the theocentric dimension CST is primarily oriented at the relationship of human beings and social institutions, not at theology of creation and reflection of the ontological value of nature. Perhaps the dynamically developing theological contributions in the sphere of theology of creation will be evaluated and critically received in the planned and announced encyclical of Pope Francis on the relationship of humans and nature, whereby the overall integral image of the relationship of God, creation, and humanity would be perfected.

\section{The Principle of Sustainable Development in Catholic Social Teaching}

Abstract The paper presents the context and development of the concept of sustainable development and asks to what extent it is applied and reflected in Catholic social teaching and the broader context of Christian ethics. It follows the development of the concept in the course of three UN conferences devoted to the environment (Stockholm, Rio de Janeiro, Johannesburg) as well as in the subsequent expert and ideological debate concerning the content and implications of the concept. It further examines the topic of development and sustainable development in the documents of the social teaching of the Catholic Church and in Christian social-ethical thought, its gradual reception and differences from its general use. In the process of intensification of ecological consciousness Catholic social teaching gradually received the concept of sustainable development in its basic meaning of intergenerational solidarity and respect to nature. However, it sets it in the broader concept of integral human development and underlines the anthropological dimension of ecological issues in the context of biblical and theological anthropology. Besides ecological and economic-developmental accents it fundamentally stresses

60 Compendium of the Social Doctrine of the Church (2004), art. 463. 
the dimension of human dignity and life from natural beginning to natural end. Thus it does not identify with the more radical ecological conceptions, which are ecocentric or biocentric in character and are overly sceptical to the perspective of the dynamics of further development, or conversely to the need to limit consumerism. Its emphasis on culture of life will be in permanent opposition to new and powerful instruments of the "culture of death", which often shroud in the agreeable garment of ecological emphases. With its accent on revising lifestyles and moderating consumption it can markedly contribute to cultivating sustainable integral development of humanity and the natural environment.

Keywords development; sustainable development; ecology; globalization; Catholic social teaching; social encyclicals; Christian social ethics; ethical anthropocentrism; ecoethics; consumerism 